Journal Homepage: -www.journalijar.com
ISSN NO. 2320-5407

RESEARCH ARTICLE

\title{
CHANGE IN MAMAK ROLE IN MULO CUCU AYAE CEREMONY IN MATRILINEAL COMMUNITY ENVIRONMENT IN SUNGAI LIUK VILLAGE PERSISIR BUKIT COUNTY, SUNGAI PENUH KERINCI CITY.
}

Sari Mustika ${ }^{1}$ and Firman ${ }^{2}$.

1. Student of Magister Program (S2) of Padang State University (UNP).

2. Profesor, Postgraduate Program at Padang State University (UNP), West Sumatra Indonesia.

\section{Manuscript Info}

\section{Manuscript History}

Received: 09 January 2019

Final Accepted: 11 February 2019

Published: March 2019

Key words:-

Change, the role of mamak, cucuayae ceremony.

\begin{abstract}
In the past until the 1990s in Sungai Liuk mamak had the obligation to carry out a ceremony when the niece of the first daughter of her sister married, named mulo сиси ayae ceremony. But nowadays that role of mamak in the implementation of mulo сиси ayae ceremony has undergone a change. The approach used in this research is a qualitative. The selection of inforants were done by porposive sampling, and the data were analyzed by the techniques of Milen and Hubermes. The results indicate that the role of mamak in the mulo сиси ayae ceremony has undergone a change of role. The role is replaced by father of orang sumando. The role of mamak in mulo сиси ayae ceremony in the past until the 90s (1) Responsible for carrying out mulo сиси ayae ceremony; (2) Coordinating fundraising for mulo сиси ayae ceremony; (3) Preparing equipment for the implementation mulo сиси ayae ceremony, now there is a change in the role of mamak in the implementation mulo сиси ayae ceremony in Dusun Sungai Liuk, such as (1) Educational factor; (2) Economic factor; (3) Factor of heirloom that have been sold; (4) Overseas factors; the occurrence of the change in the role of the mamak during the mulo сиси ayae ceremony in Sungai Liuk; (1) The figure of mamak is less respected by nephews; (2) The authority of mamak begins to fade in the midst of society and sumando (3) Changes in structure and responnsibilities in the family; (4) Conflicts faced; (5) Conflict of inheritance.
\end{abstract}

Copy Right, IJAR, 2019,. All rights reserved.

\section{Introduction:-}

The Kerinci community use a matrilineal kinship system that is based on the mother's line age. So that in the Kerinci community a mamak has a social obligation and is responsible for the welfare of his kamanakan. In the Kerinci customs, the role of mamak in a normative manner, namely Mamak, plays a role in educating, guiding inheritance, supervising education, and asking questions, including education by nephews. Mamak also plays a role in the field of inheritance is to maintain, supervise the use, and develop inheritance, maintaining that customary assets continue to function in accordance with traditional provisions. Mamak also plays a role in the development of his people's assets so that the welfare of his people, including his nephews, can be guaranteed. The role of mamak in niece marriage is to find a mate for the niece of the nephew in particular, the person in charge of the full marriage

Corresponding Author:-James E Curtis.

Address:-Jr, igri, po box 3126, washington dc 20010. 
agreement, mamak is also responsible for the cost of the nephew's marriage, but if mamak is underfunded the inheritance may be pawned for the continuity of the wedding. Mamak also acts on behalf of the family to solve a problem. In the prover it is stated that the role of a Mamak is: "The child is in his lap, Kamanakan is buried" (Zakaria 1984: 165).

Sanderson in Firman (1997: 6) reveals that the people who adhere to the matrilineal system give rise to two basic types of "fatherhood", namely "biological fidelity" and "sociological fidelity". Married men are said to be the biological fathers of their own children. Whereas the sociological father is a man who has the primary responsibility for caring for the children of his parents. This often creates tension in matrilineal society.

Social changes that occur in the Kerinci community, which can be seen from the structure of the matrilineal system itself. The child or niece has been cared for or lived with the nuclear family consisting of father, mother and children compared to living with a broad family consisting of grandmothers, children and grandchildren who live in one house. The changes will also be seen in the implementation of the Mulo Cucu Ayae ceremony where in the past until the 1990s the ceremony was carried out by the mamak, but at this time mamak was unable to carry out the Mulo Cиси Ayae ceremony when the niece married, the role was taken over by the father or Orang sumando.

From the explanation above, it can be seen that the occurrence of changes in this matter, the role of mamak in the ceremony of mulo сиси ауаe, this also has an impact on social institutions and the values of their customs. Therefore, this research is important because in community life especially on the Sungai Liuk, the mulo cucu ayae ceremony is one of the conservation forms of local custom that is carried out from the past to the present, the process of kinship between mamak and his niece; Mulo Cucu Ayae is also a form of solidarity among fellow mamak for his niece. But by looking at the changes in the role of the mamak at the Mulo Cucu Ayae ceremony in Sungai Liuk Hamlet, researchers were interested in seeing the role of mamak at Mulo Cиси Ayae ceremony and the impact of this change in Sungai Liuk Hamlet at this time in which there was a change in the role of mamak in the mulo cucu ayae ceremony.

\section{The Method of Research}

This research is a qualitative approach, this approach was chosen because it can open opportunities to express the impact of the change in the role of mamak in mulo сиси ayae ceremonies sharply and deeply based on the meaning given by the research subject (native point of view). The study was conducted in Sungai Liuk Hamlet, Pesisir Bukit District, Sungai Penuh City. This village was chosen because the only hamlet that carried out the mulo cucu ayae ceremony when the first daughters were married. Dusun Sungai Liuk consists of four villages, namely Sungai Liuk, Koto Dua Village, Seberang Village, and Sumur Gedang Village.

The selection of informants were done intentionally (purposive sampling), namely the deliberate withdrawal of informants in accordance with the objectives of the study. Informants who have been estimated to have extensive knowledge and have experiences in mulo сиси ayae ceremonies in depth. This technique was chosen because researchers already understood the mapping of subjects believed to understand and know about mulo cucu ayae. The total number of informants in this study were 27 people. This research was conducted on November 10,2017 to November 25, 2018. Interviews conducted were in-depth interviews. The researcher conducted in-depth interviews with informants to obtain detailed data on the impact of the change in the role of mamak in the mulocucuayae ceremony on the Sungai Liuk community by asking questions based on interview guidelines that had been made before the field. Data analysis in this study is an analysis technique from Miles and Huberman namely Data Reduction, Display or data presentation and conclusion and data verification.

\section{Research result}

In the results of this study, researchers describe the data obtained from field research in the form of interviews, direct observations and supporting documents. The description of the data intended in this study is a description of the facts and various information obtained through approaches based on the framework of thinking and methods recognized by scientific principles, departing from the formulation of the problem, the findings during conducting research will be explained as follows:

1. The Role of Mamak in the Mulo Ceremony of Ayae's Grandson

The role of mamak for her nephew children is found in everyday life, for example guiding the niece in accordance with the traditional proverb, telling the child in the nephew to be guided, giving advice, funding the nephew, finding 
a mate, and giving to those who are in trouble and needing help. This means that mamak is obliged in terms of traditional ceremonies, from the moment of birth, marriage, to death

The role of mamak in Dusun Sungai Liuk, Pesisir Bukit Sub-district was initially seen at the time of niece, the first child of his sister to marry. Mamak will carry out a ceremony which is the mulo cucu ayae ceremony as a thanksgiving that his niece is married, and will continue the descendants of her family and her family. In Sungai Liuk community, they hope to have daughters because inheritance are entrusted to girls. If a family does not have a daughter, then no one will continue the descendants of the heart to inherit the title of Pusako. The role of mamak at mulo сиси ayae ceremony when the niece of the firt female child from her sister is married, namely: (a) is responsible for carrying out the mulo сиси ayae ceremony; (b) coordinating the collection of funds for mulo cucu ayae ceremonies: and (c) preparing equipment for the implementation of the mulo cucu ayae ceremony.

\section{There was a change in the role of mamak in the matrilineal community during the ceremony of mulo cucu ayae}

In essence the relationship between mamak and nephew in Sungai Liuk is a relationship of blood relations, in its ideal pattern the relationship between mamak and niece can be seen in mamak carrying out customs, fulfilling the economic needs of extended families, supervising inheritance and inheriting values and carrying out ayae granddaughter ceremonies when niece of the first daughter of his sister. The role of mamak in the past was quite heavy, with the current changes caused by several factors, these changes would have an impact on the role of mamak in the mulo сиси ayae ceremony.

Mamak's role in Sungai Liuk village will not be at the time of the niece of the first married woman, where the role of mamak in carrying out the mulo сиси ayae ceremony has been taken over by a sumendo father or person so that the child or niece will marry and what day the implementation of the mulo сиси ayae ceremony will be determined by me. Previously before carrying out the mulo сиси ayae ceremony, mamak is going to a deliberation first or holding angimbujantong was decided by all the decisions starting from the day of consent, the day of the mulo cucu ayae 's implementation would be determined by mamak. Mamak was the one who had the role in breaking everything because the costs were also borne by mamak, so before ngimbu jantong dimundalea no other person should know including the family of the father when the marriage would take place, the implementation of mulo cucu ayae, and invitations should not be revealed.

Now this has changed because not the mamak is responsible for the continuation of the mulo cucu ayae ceremony, so calling for jantong is only a formality, because at the time of ngimbu jantong dimundalea the father's family also participated, and the implementation of ngimbu jantong dimundalea at the moment three days before Ijab Kabul, where other people already knew when the wedding day, mulo cucu ayae 's day and invitation had spread. So mamak is currently disappointed because in calling on the jantong dimundalea he no longer decides everything but now he only accepts decisions from the people of Sumando.

Social change is not a sudden process. In general there are several factors that contribute to the emergence of social change. These factors are classified in and out of society. Factors originating from within: (1). Increased and reduced population; (2). New discoveries, while external factors: (1). The occurrence of natural disasters or physical environmental conditions; (2). In addition, there are also factors that encourage (accelerate) and hinder the process of social change, among others: (1). Contact with other cultures; (2) advanced formal pendidian systems; (3). The tolerance of change is distorted, and so on. While the factors that hinder the process of social change include: (1). Lack of relations with other communities; (2). Social contact (social interaction) is lacking with other communities; (3). Very traditional attitude of society; (4).The fear of shaking in the integration of culture, etc.

Based on data and facts gathered in the field, quite a lot of things have happened in the process of social change. Factors that cause changes in the role of mamak at mulo cucu ayae ceremony in Sungai Liuk Hamlet are: (1) educational factors; (2) economic factors; (3) factors of inheritance that have been sold; (4) migratory factors.

\section{Acknowledging the Change of Mamak's Role in MuloCucu Ceremony}

Based on the description of the data obtained in the field, due to changes in the role of the mamak in the mulocucu ceremony also had an impact on the relationship between the mamak and the niece. In more detail, it can be identified as a result of the change in the role of the mamak at the mulo cucu ayae ceremony: 
a. The Mamak figure is lacking in respected by nephews.

The lack of functioning of the mamak against the nephew makes the niece less appreciate and dislike the mamak. This is because the niece does not need to respect her mamak anymore because mamak is no longer influential in her life, where mamak is no longer a person who decides when she wants to get married so they no longer need to ask her permission if she wants to get married. So in the community of Dusun Sungai Liuk at this time it is rare for those who marry a mamak child, because they have dared to refuse an arranged marriage from mamak, in addition to a ceremony held by the Dusun Sungai Liuk community namely mulocucuayae ceremony the role of mamak here is very clear it has changed, usually during the ceremony of mulocucuayae carried out by mamak who held the role and mamak who regulated everything father not only married his son.

The lack of mamak participation in the mulo сиси ayae ceremony will have an impact on the relationship of the mamak with the niece and relationship of the mamak with his sister. The figure of mamak is less respected by niece, where mamak should be respected and respected by nieces and nephews, but now with the change in the role of mamak in the mulo grandchildren ayae ceremony will have an impact on mamak figures who are less respected by nephews.

b. The authority of Mamak began to fade in the middle of society and Sumando

The lack of functioning of the mamak against nephews can cause uncontrolled well. Control of mamak is needed for the good of his nephew. If the niece makes a mistake in the community the first time it becomes a question for the community who is mamaknya. Likewise for the Sungai Liuk community when the first girl wants to get married who is questioned by the community and the party from the male family is mamak, because the male side wants to meet his mamak first before the wedding is held. So if the first married child in Dusun Sungai Liuk does not carry out the mulo сиси ауаe ceremony then mamak is fined by adat and mamak will be ridiculed by the local community.

But at this time has undergone a change mamak not ready to carry out the mulo cucu ayae ceremony when the merriage with his nephew, so that when the nephew married and mamak is not important anymore, sometimes mamak when the nephew married do things that he should not do such as helping set up a stage, tent, sticking firewood. Mamak here should be the person who assigns or instructs other people to work during the wedding of his niece.

c. Changes in the Structure and Responsibilities in the Family

There has been a change in the structure of power in the family. The ones who are in charge in the family should be mamak, but at the present time the number of mamak who migrate and the unpreparedness of mamak in fulfilling their needs for settlement is also caused by ulayat land which has been sold out. So that the transition of power to switch to Sumando or the father of the nephew. The function and role of mamak begins to diminish so that all things related to niece are taken care of by sumando or the father of the nephew. Changes in the power structure in the family in Sungai Liuk Hamlet are partly caused by: (1) the mamak who migrate means leaving the territorial origin and occupying a new territory, this also means leaving the inheritance in the form of ulayat land which was used as the main source of the family economy; (2) mamak who migrate means moving from the old social environment to the new social environment and living side by side with other tribes, this provides an opportunity for acculturation.

The shift of power in the family from mamak to father because of leaving territorial customary law, the grip of customs has weakened. Mamak can no longer carry out his will towards nephews. By leaving the territorial law of customary means the family leaves the inheritance. So this indicated the responsibility to finance the mulo grandson ayae ceremony when his nephew married and his niece economy, because mamak no longer worked on inheritance, so it was father who took the full role of financing the needs of the mamak's child or niece.

\section{d. Conflict faced}

The change in the role of the mamak during the mulo cucu ayae ceremony also gave rise to conflict in the family, where during this ceremony the married niece was no longer asking permission from her mamak. In around the 90s, nieces met mamak first before getting married, and sometimes the mamak already had a candidate for his nephew. However, now that the mamak does not approve of the marriage of the niece of mamak, she will be left behind and not listened to her words, because mamak can be too hard to investigate and determine her marriage, this is because the mamak is no longer issuing funds during the mulo granddaughter's ceremony. So that at the time of the niece's marriage, women at this time, mamak often had conflicts with his father's family, because they were fighting over to play a role in the mulo сиси ayae ceremony, many of them were exiled when they married. 
The change in the role of mamak in the mulo сиси ayae ceremony also led to a conflict between mamak and niece, mamak and his sister. In the past, nieces and female relatives of mamak were afraid of having problems with mamak, they always maintained that the relationship with mamak was well-established, because mamak was a powerful person and the place of niece was dependent and protecting. So that the niece and her mother know the sister follows the will of mamak because the peacock is afraid that mamak will pawn the inheritance and no one will help them when they are troubled and facing problems.

e. Heritage Treasure Conflict

The change from the role of mamak to the mulo сиси ayae ceremony was also based on inheritance, this caused a conflict of inheritance, where the mamak used to play a role and hold power over the inheritance, but nowadays the mamak has not been approved by his sister who has the right to regulate inheritance. In the 90s mamak had the right to process inheritance, and his brother was afraid of mamak, if mamak wanted to ask for rice, borrowed money and worked on the inheritance, his sister would give them, they could not refuse the wishes of mamak. However, at this time there were many conflicts in conflict between Mamak and his sister and niece regarding inheritance.

The release of the responsibility of the mamak to the niece makes mamak no longer valued, respected and also causes conflicts over inheritance, the daughter does not want the son or mamak who has the power over the inheritance because the yield of the inheritance is no longer given to her son, because mamak is more concerned with its core family.

\section{Conclusion:-}

Changes in the role of mamak which occurred during the mulo cucu ayae ceremony in Sungai Liuk village, Pesisir Bukit Sub-district, Sungai LiukKerinci City based on the results of the study were caused by factors from outside and from within the community. Besides that, based on the data and facts that have been collected in the field, there are quite a lot of things that occur in the social change process. The factors that cause changes in the role of mamak in mulocucuayae ceremonies are education, economy, sold property, and wandering. From the change in the role of the mamak during the mulo сиси ayae ceremony, it also caused a conflict between mamak and niece, mamak (brother) with a sister.

As a result of the change in the role of mamak at the mulo сиси ayae ceremony, the mamak figure is not respected by kemenakan, the authority of mamak begins to fade in the community due to the fading of friendship and mamak's relationship with niece, and it is the structure and responsibility of the father's family that has an important role in the family now both from education, guiding, educating and carrying out mulo cucu ayae ceremonies when the first child is married.

\section{References:-}

1. Afanti, Septa. (1984). Tambo Sakti Alam Kerinci: Buku Pertama. Jakarta. Retrieved from Depertemen Pendidikan dan Kebudayaan Proyek Penerbitan Buku Sastra Indonesia dan Daerah

2. Afanti, Septa. (2007). Sejarah Kerinci (Kincai). Jakarta: Dian Rakyat.

3. Budhi, Vrishasphati dan Eka Putra Depati. (2013). Senarai Sejarah Kebudayaan Suku Kerinci. Jambi: Bina Potensia Aditia Mahatva Yodha Sungai Penuh dan Kerinci.

4. Bugin, Burhan. (2006). Analisis Data Penelitian Kualitatif. Jakarta: Raja Grapindo Persada.

5. CH. N. Latief Dt, Bandaro. DKK. (2003). Minangkabau yang Gelisah: Mencari Strategi Sosialisasi Perwarisan Adat dan Budaya Minangkabau untuk Generasi Muda. Bandung: Lubung Agung.

6. DJakfar dan Idris. (2001). Menguak Tabir Prasejarah di Alam Kerinci. Sungai Penuh: Pemerintah Kabuopaten Keinci.

7. Firman. (2018). Posisi dan Fungsi Mamak dalam Perubahan Sosial di Lingkungan Keluarga Matrilinial Minangkabau.Universitas Negeri Padang.

8. Havilland, William. A. (1988). Antropologi Jilid 1. New York. Retrieved from CHS College Publishing

9. Horton, Paul B dan Hunt, Chester L. (1999). Sosiologi Jilid 1. Jakarta: Erlangga.

10. Iskandar, Zakaria. (1984). Tambo Sakti Alam Kerinci. Kerinci: Departemen Pendidikan dan Kebudayaan.

11. Kavlan Davit dan Alber A Mannert. (1999). Teori Budaya. Yogyakarta: Pusta Pelajar.

12. Koentjaraningrat. (1972). Beberapa Polol Antropologi Sosial. Jakarta: Dian Rakyat.

13. Lauer, H. Robert. (1993). Perspektif Tentang Perubahan Sosial. Jakarta. Retrieved from Rineka Cipta.

14. Mangku. (1992). Mengenal Hukum Adat Kerinci dan Hak Kewajiban Tengganai, NINIK Mamak dan Pemangku 
dalam Membina Persatuan dan Kesatuan serta Kerukunan Hidup di Desa dalam Kabupaten DATI II Kerinci. Sungai Penuh: Kabupaten DATI II Kerinci.

15. Martono, Nanang. (2014) Sosiologi Perubahan Soaial: Perspektif Klasik, Modern, dan Postkolonial. Jakarta: Rajawali Pers.

16. Matew B. Miles dan A. Michel Huberman. (1992). Analisis Data Kualitatif. Jakarta: UI-Press.

17. Moleong, Lexy J. (2009). Metode Penelitian Kualitatif. Bandung: Remaja Rosdakaya

18. Parsons,Talccot. (1986). Fungsionalisme Imperatif. Jakarta: CV Rajawali

19. Ramli, Thahar \& Yasmina. (2005). Biografi H. A. Thalib (1918-1973): Perjuangan Dari Bumi Sakti Alam Kerinci. Padang: Yayasan Citra Budaya Indonesia.

20. Rizer,Geoge dan Goodman J, Dounglas. (2004). Teori Sosiologi Modern. Esiai 6. Jakarta: Kencana Prananda Media Group.

21. Sanderson, Stephen K. (2000). Sosiologi Sebuah Pendekatan Terhadap Realita Sosial (terj). Jakarta. Retrieved from Rajawali Perss.

22. (terj). Jakarta. Retrieved from Rajawali Perss. 